\title{
Implementing Guiding Questions Combined with Animation Film to Improve Ninth Graders' Narrative Writing Skill
}

\author{
Siswanjaya ${ }^{1)}$, Ali Saukah ${ }^{2)}$, Francisca Maria Ivone ${ }^{2)}$ \\ ${ }^{1)}$ SMPN I Terbanggi Besar, Lampung Tengah \\ ${ }^{2)}$ English Language Teaching-Universitas Negeri Malang \\ Jl. Budaya, Poncowati, Lampung Tengah, E-mail: siswanjaya@yahoo.com
}

\begin{abstract}
This Classroom Action Research was aimed at improving students' narrative writing ability at SMPN I Terbanggi Besar, Central Lampung. Lampung, Indonesia. The subjects were 34 students of class IX E. The researcher used writing test as the instrument. The findings showed that the strategy could improve ninth graders' writing narrative ability. It's highly recommended that the English teacher use guiding questions combined with animation film to improve the students' narrative writing ability and the future researchers are suggested to conduct further studies related to the implementation of guiding questions combined with animation film with different kinds of texts and students level.
\end{abstract}

Key Words: writing skill, narrative text, guiding questions, animation film

\begin{abstract}
Abstrak: Penelitian tindakan kelas ini bertujuan meningkatkan kemampuan siswa menulis text narrative di SMPN I Terbanggi Besar, Lampung Tengah, Lampung, Indonesia. Subjek penelitian ini adalah siswa kelas IX E yang berjumlah 34 siswa. Instrumen penelitian ini adalah tes menulis. Hasil penelitian menunjukkan bahwa strategi ini dapat meningkatkan kemampuan menulis narrative siswa kelas IX. Peneliti sangat merekomendasikan kepada guru bahasa Inggris untuk menggunakan guiding questions dikombinasikan dengan film animasi untuk meningkatkan kemampuan siswa menulis teks narrative dan peneliti menyarankan kepada peneliti selanjutnya untuk melaksanakan penelitian berhubungan dengan penerapan guiding question dikombinasikan dengan film animasi pada jenis teks dan tingkat siswa yang berbeda.
\end{abstract}

Kata kunci: kemampuan menulis, teks narrative, pertanyaan penuntun, film animasi

Writing activity gives much benefit for students and chances to practice their English. Students can express their ideas, develop their vocabulary and grammar and communicate their goals through writing. Huy (2015) confirms that developing students' vocabulary and grammar, improving their ability to use language and supporting other language skills can be done through writing activity. In addition, Javed, Juan and Nazli (2013) conclude that writing skill has a significant role to improve students' exposure and ability with the goal of communication and interaction.

Unfortunately, writing is not as easy as placing words on paper. For students of junior high school, they faced many problems to write, one of them is writing narrative text.

Based on the preliminary study, the researcher found that the students had poor idea to write narrative text, the students had difficulty to write narrative text in chronological order, they had limited vocabulary and the students were not motivated and interested with the teacher's teaching techniques and media. In addition, based on the writing test, the students' lowest score was 39 out of 100 , the highest score was 77 out of 100 and the mean score was 58,1. There were only 7 students who got score more than the passing grade, 70.

Due to those problems, the researcher implemented a strategy in this research to overcome it. The researcher used guiding questions in teaching narrative text. Guiding questions is believed to have many advantages.

Guiding questions helps students plan their writing and gives students a chance in structuring sentences (Raimes, 1983, p. 101; Al Gharabally, 2015, p. 42), 
guiding questions help to overcome students' problem in organizing and generating ideas of writing narrative text(Fauzan, 2009), and it can improve students writing narrative text in the aspect of language use (Jayanti, 2015).

To strengthen the guiding questions in overcoming the students' narrative writing problem, the researcher combined it with animation film. There are many advantages of using animation film related to students' narrative text writing. Animation film can help students to overcome their problem in writing in terms of generic structures and stimulate students' ideas (Anggraeny, 2015), the students will easily get the idea and understand the story since it is conveyed through expression, language, sound and gesture (Zulfadlan, 2013), and the students can catch the idea because they can watch and know the plot (Akmala, 2011).

\section{METHOD}

This Classroom Action Research following Kemmis and Taggart Model (1988) was conducted at grade IX of SMPN I Terbanggi Besar, Central Lampung, Lampung, Indonesia. It covered the four stages of Classroom Actions Research; Planning, Action, Observing and Reflection. It was done in 3 cycles, two meetings for the first cycle, three meetings for the second cycle and three meetings for the third cycle. The researcher used writing test as the instrument to know the students' achievement in writing.
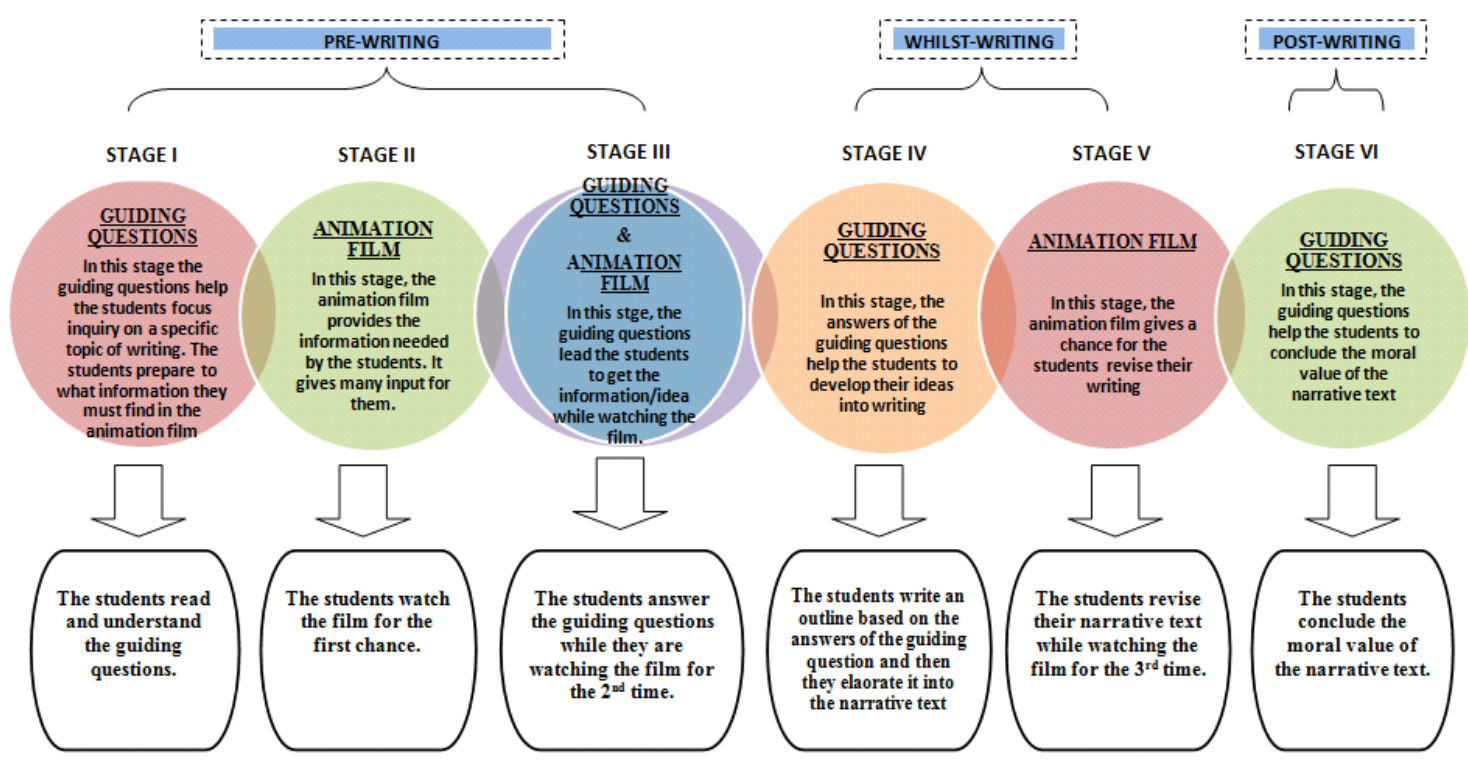

Figure 1. The stages of Developing Guiding Questions Combined with Animation Film to Teach Writing Narrative Text
In the preliminary study, the researcher tried to know the students' narrative writing problems by interviewing the English teacher, giving questionnaire to the students and administering writing test.

In order to implement the guiding questions combined with the animation film, the researcher developed the stages of the writing into six stages which can be seen in Figure 1.

Besides the activities in those stages, the researcher put supplementary actions to get better result in this research. The supplementary actions were; providing explanation of the text structure and language features, providing explanation of grammatical pattern, discussing the words from the animation film and giving pair feedback.

There were verbal and numerical data in this stage. The verbal data was the description of the students' writing result and the numerical data was taken from the students' writing test score. The students' writing test was assessed from the aspects of content, organization, vocabulary, language use and mechanics. The assessment rubric is taken from Jacobs, et al (as cited in Hughes 2003, p. 104).

The researcher set 3 criteria of success to conclude that the strategy could improve the students' narrative writing ability. First, the students who got score below the passing grade (KKM) in the preliminary study can improve their score at least by 12 points in average. Second, the average score of all students is equal to or more than 70 . Third, $80 \%$ students or more can reach the minimum passing grade, 70 . 


\section{Data Presentation And Research Findings}

In this study, the researcher focused on the students' writing improvement. The researcher conducted writing test in the preliminary study to know the students' narrative writing ability. The researcher found that the students were low in all aspects of writing. The mean score was 58.1. There were only 7 students who got more than the passing grade, 70 (Table 1).

Then the researcher conducted the first cycle of this study (Table 2). It was conducted in two meetings. The researcher found that there were improvement of the students' writing aspects and the final score but it only fulfilled the three criteria of success.
The researcher continued to Cycle II by revising the strategy (Table 3). At Cycle II, the researcher provided more time to explain the language features of narrative text especially simple past tense, reset the time allocation of each writing stages, gave and explained an example of outline and provided time for students to recheck their writing in mechanics aspects.

The researcher conducted the six stages of narrative writing in 3 meetings. The researcher found better result of the students' narrative writing at Cycle II. Based on the writing result, the researcher identified that the first and the second criteria of success had been achieved but the third had not.

Since the third criterion had not been achieved, the researcher continued to Cycle III (Table 4). There

Table 1. The Students' Writing Result in the Preliminary Study

\begin{tabular}{|c|c|c|c|c|c|c|}
\hline Score & $\mathrm{C}$ & $\mathrm{O}$ & $\bar{V}$ & $\overline{\mathrm{LU}}$ & $\mathrm{M}$ & FS \\
\hline Max & 24 & 16 & 17 & 18 & 4 & 77 \\
\hline Min & 13 & 8 & 8 & 5 & 2 & 39 \\
\hline Mean & 18,3 & 12,4 & 12,2 & 12,5 & 2,7 & 58,1 \\
\hline $70<$ & \multirow{2}{*}{\multicolumn{6}{|c|}{$\begin{array}{l}27 \text { Students } \\
7 \text { Students }\end{array}$}} \\
\hline $70=$ & & & & & & \\
\hline
\end{tabular}

Table 2. The Result of the Students' Writing Score at Cycle I

\begin{tabular}{|c|c|c|c|c|c|c|}
\hline Score & C & $\mathrm{O}$ & V & LU & M & FS \\
\hline Max & 27,5 & 18 & 17,5 & 16,5 & 3,5 & 82,5 \\
\hline Min & 16,0 & 12 & 10,5 & 10,0 & 2 & 53,5 \\
\hline Mean & 22,5 & 15,2 & 14,4 & 13,3 & 3,0 & 68,2 \\
\hline $\begin{array}{l}70< \\
70=\end{array}$ & \multicolumn{6}{|c|}{$\begin{array}{l}18 \text { Students } \\
16 \text { Students }\end{array}$} \\
\hline
\end{tabular}

Note: Max : The highest score, Min : The lowest score, $\mathrm{C}$ : Content, $\mathrm{O}$ : Organization, V : Vocabulary LU : Language Use, M : Mechanics, FS : Final Score.

Table 3. The Students' Writing Result at Cycle II

\begin{tabular}{lllllll}
\hline \multicolumn{1}{c}{ Score } & $\mathrm{C}$ & $\mathrm{O}$ & $\mathrm{V}$ & LU & $\mathrm{M}$ & FS \\
\hline Max & 27,5 & 18,5 & 17,5 & 20 & 4,5 & 82,5 \\
Min & 16,0 & 11,0 & 11,0 & 11,5 & 2,0 & 53,5 \\
\hline Mean & 23,2 & 15,9 & $15,0 \quad 14,5$ & 3,3 & 68,2 \\
$\mathbf{7 0}<$ & \multicolumn{7}{c}{ 22 Students } \\
$\mathbf{7 0 =}$ & \multicolumn{7}{c}{ Students } \\
\hline
\end{tabular}

Note: Max : The highest score, Min : The lowest score, $\mathrm{C}:$ Content, O : Organization, V : Vocabulary LU : Language Use, $\mathrm{M}$ : Mechanics FS : Final Score.

Table 4. The Students' Writing Result at Cycle III

\begin{tabular}{lcccccc}
\hline \multicolumn{1}{c}{ Score } & C & O & V & LU & M & FS \\
\hline Max & 28,5 & 18,5 & 18 & 22 & 5 & 91 \\
Min & 20,5 & 14,0 & 13 & 12,5 & 2,5 & 64,5 \\
\hline Mean & 24,9 & 17,9 & 15,8 & 16,6 & 3,8 & 78,1 \\
$\mathbf{7 0}<$ & \multicolumn{7}{c}{ 2Students } \\
$\mathbf{7 0 =}$ & \multicolumn{7}{c}{ 29 Students } \\
\hline
\end{tabular}

Note: Max : The highest score, Min : The lowest score, C : Content, O : Organization, V : Vocabulary

LU : Language Use, M : Mechanics FS : Final Score. 
was a little change of the strategy. The researcher provided time to explain simple past tense and gave an example of narrative text to analyze the use of simple past tense in it, played and paused the animation film, and provided time to have pair feedback.

The Cycle III was conducted in 3 meetings. Based on the writing result, the researcher identified that it had fulfilled all the criteria of success.

Based on the result of Cycle III, the researcher decided to stop the cycle since the result has fulfilled all the criteria of success in this study.

\section{DISCUSSION}

This chapter focuses on the discussion of the research findings presented in the previous chapter. The discussion is focuses on how guiding questions combined with animation films can improve ninth graders' narrative writing ability.

Based on the result of the writing test, the researcher inferred that guiding questions combined with animation film could improve students' writing narrative ability. It was showed by the improvement of the students' writing narrative skill in all components; content, organization, vocabulary, language use and mechanics. Those improvements were also supported by the supplementary actions such as; explaining the text structure and language features of narrative text, explaining the grammatical pattern, discussing the words from the animation film and giving pair feedback.

The researcher believes that both of guiding questions and animation film have strengths to overcome students' problems in writing narrative text. The researcher combined them in order to have better result of the students' narrative writing. The teacher then developed 6 stages of writing in this study.

In the beginning of each cycle, the students were given the guiding questions to understand. In this stage, the students looked active to know what information they had to find in the animation film. It indicated that giving guiding question as pre-writing activity was very worthwhile for the students. It facilitated the students to prepare them to what they were going to know and understand. It supports Al Garabally (2015) who gives suggestions that giving questions is one of ways to plan writing in order to make writing task less threatening. It is also in line with Traver (1998) who says that guiding question is the fundamental query that directs the search for understanding.

In the stage of answering the guiding questions, the researcher let the students use their own strategy to answer it, whether they answered the guiding questions directly while watching the animation film or they answered it after they watched it. The researcher didn't prohibit them to take note while they were watching the animation film. By answering the guiding questions while watching the animation film, the students got much information needed to be elaborated in their writing. It is in line with the research result of Lawson (2006) which concludes that asking the students to answer guiding questions while they were watching video or film increases how much information they get from the video or film.

The animation film gives more ideas to the students to write their narrative text since the students can understand the content of the film from the picture, the characters' voice, and gesture. For example, the students mentioned not only the character but also described what it looked like. It is in line with Harmer (2001, p. 282) who says that one of the advantages of using film is the students can see the language in use. The students not only hear but they also can comprehend the content of the film, for example, they can get the general meaning and moods which are often conveyed through expression, gesture, and other visual clues and they can observe how intonation can match facial expression.

It is good choice of using animation film to deliver the material in this study. When the teacher uses animation film, it means that the teacher has applied the use of multimedia in their teaching learning activity. Multimedia has important advantages in the classroom activity. During the classroom activity, the researcher noticed that the students were interested and motivated so the students kept focusing their attention on the material. It was in line with Mayer (2005) "Individuals can effectively learn through visual context. Multimedia principle greatly facilitates learners' understanding. Lessons containing words (printed or spoken) and pictures (illustrations, photos, animations, or video) enhance learning".

Understanding the guiding questions, watching the animation film and answering the guiding questions were stages in the pre-writing of this study. Giving enough activity and time in the pre-writing is necessary in order to supply input for the students and make them ready to write. It is supported by Urquhart \& McIver (2005, p. 12) who confirm that pre-writing is important stage in writing which is often neglected. The students have to spend more time in pre-writing activities in which one of activities in pre-writing is giving questions to the students. By doing so, the stu- 
dents can understand about their topic and sketch an outline or framework to write.

Furthermore, to help the students elaborate the answers of the guiding questions to be more arranged, the researcher asked them to make an outline based on the answers of the guiding questions. By having an outline, it was helpful for the students to write their text in more details. It is in line with Widarso (as cited in Akmala, 2011) who says that "one way of good stimulus to get writing process easier for students is a set of questions which are related to each other. By answering the questions and arranging the answers in a paragraph it will create a simple text"

Providing time to have pair feedback was one of supplementary actions in this study. It was effective to minimize the students' error in mechanics aspect. It can be seen in the result of Cycle III. The mean of the students' mechanic aspect was improved better than the previous cycle. It supports the finding of Nuraeini (2014) which concludes that students' narrative writing text can be improved through peer feedback between students.

Referring to the research finding at Cycle I, there were improvements in all aspects of writing. The mean score in preliminary study was 58.1 meanwhile at Cycle it was 68.2. There were 16 students who got score 70 or more. The students who got score under the passing grade in the preliminary study could improve their score 11,6 points in average. The researcher notices that the content and organization aspect increased higher than other writing aspect. Even though the students' writing result were improved compared to the preliminary study but it had not met the three criteria of success.

The researcher took a conclusion that Cycle I had not met the criteria of success since it was possibly caused by many factors. First, the teacher didn't provide enough time to explain the language features of the narrative text especially to explain about simple past tense. It can be seen from the students' writing result at Cycle I. Most of the students used simple present tense in writing their narrative text. Second, the teacher played the animation film in hurry to move to other steps of writing. The teacher didn't pay attention whether the students had understood the content of the film so they could not understand the whole film well. Third, the teacher didn't give enough explanation and example of an outline so even though the students made their own outline, it didn't help them much to elaborate their writing. Fourth, the teacher didn't remind the students to check the mechanics aspect of their writing. It is very important for minimizing the students' errors in this writing aspect.

At Cycle II, the researcher notices that there were better writing result compared to the preliminary study and Cycle I. The mean score of the students' writing was 72.1 . There were 22 students who got 70 or more. The students who got score under the passing grade in the preliminary study could improve their score 18.8 points in average. The result of this cycle has achieved two of the three criteria of success.

The researcher notices that all aspect of writing improved better than in the preliminary study and Cycle I. The researcher was sure that it was caused by using revised teaching procedure at Cycle II. Explaining the language features of the narrative text was effective to make the students aware of their writing especially for language use aspect. Most of the students could apply simple past tense in their writing well even though there were some students got misunderstanding about it by changing all the verb into past form. Setting up the time allocation for each stage was also helpful for the students to do their activity in each stage well. For example, the students could understand the animation film better by having enough time. Explaining and giving an example of outline was also help the students to make better outline in order to be elaborated into their writing. The last, providing time to recheck the students' writing in mechanics aspect helped the students to minimize their errors but it was not so significant so that the researcher tried to revise it.

At Cycle III, the students' writing narrative text skill was improved highly better the preliminary study. The mean score of this cycle was 78.1 and there were 29 students got 70 or more. The students who got score under the passing grade in the preliminary study could improve their score by 22 points. The researcher noticed that the revised strategy was successful in improving the students' writing ability. The researcher concluded that the revised teaching procedures was helpful the students to improve their writing ability.

Based on the result above, it can be seen that guiding question combined with animation film can improve student's narrative writing skill. It gives information to the previous studies. In the previous studies, Rahman (2012), Pertiwi (2013), and Melianti (2014) conclude that guiding questions could improve students' writing skill for recount text at grade 8 but this research proved that guiding question can also be implemented for narrative text at grade 9. Meanwhile, Ikhda (2014) and Jayanti (2014), conclude that guiding questions can improve students' writing for descriptive and 
narrative text at grade 10 and 12 of senior high school but the result of this research gave information that guiding questions was also appropriate for the lower grade, junior high school.

The researcher concluded that the improvement of the students' narrative writing skill was mostly caused by the strategy but the researcher also realized that supplementary actions such as explaining the text structure and language features of narrative text, explaining grammatical pattern, discussing the words from the animation film and giving pair feedback. It supports Agusta (2014) and Gusparia (2014) who concluded that using animation film could improve the students' narrative writing skill in all writing aspects but it needed other supplementary actions to have better results.

Overall findings based on the result of this study, the researcher noted that combining guiding questions with animation film gives better result of the students' narrative writing skill. Both guiding questions and animation film have advantages for the process to the result of the writing.

The main limitation of this study is the teacher was too busy in distributing the guiding questions and operating the laptop or computer so the teacher could not pay attention to all students well. In term of time, it was a little bit difficult for the teacher to manage the time because the student could not use the available time well.

\section{CONCLUSIONS}

Based on the research process and the research findings, the researcher draws conclusion as follows.

First, the implementation of the guiding questions combined with animation film can improve the students' writing narrative skill for ninth graders of SMPN I Terbanggi Besar, Central Lampung. From the mean score of the writing test, we can see that in the preliminary study the mean score was 58.1 meanwhile in the Cycle III the mean score was 78,1 .

Second, the improvement of the students' writing narrative text was caused by the strategy and supported by supplementary actions such as; providing explanation of the text structure and language features, providing explanation of grammatical pattern, discussing the words from the animation film and giving pair feedback.

Considering the result of the research findings, the researcher gave some suggestions for the readers of this research report as follows.
Firstly, for the teacher who will implement the guiding questions combined with the animation film, he/she should prepare it well; the teacher has to choose the appropriate animation film, make the guiding questions based on the animation film, and the teachers have to be capable in multimedia and technology since they will use many facilities such as laptop, speaker, and LCD. Then the teachers also need to be aware with the time management since the students will do it in some stages.

Secondly, for further researcher, the findings of this research can be used as reference to conduct further research related to the implementation guiding questions combine with animation film to improve students' narrative writing skill. Further researches are suggested to conduct similar research on similar language skill but they may use different grade and text. The researcher also suggests identifying the students' perception towards the strategy using observation and questionnaire.

\section{REFERENCES}

Agusta, D. (2015). Improving students' ability in writing narrative texts using short animated stories at class VIII C of SMPN 2 Sanden, Bantul in the academic year of 2013/2014 (Unpublished bachelor thesis). Retrieved from http://eprints.uny.ac.id/ 26574/1/Skripsi.pdf.

Al-Gharabally, M. (2015). The writing difficulties faced by $\mathrm{L} 2$ learners and how to minimize them. International Journal of English Language and Linguistics Research, 3(5), 42-49.

Anggraeny, E.D. (2015). The use of animated video to teach writing narrative text. Retrieved from http:// ejournal.unesa.ac.id/article/13992/58/article.pdf.

Akmala, T. A. (2011). The use of animated film to improve students' ability in writing narrative text (Unpublished master's thesis). Walisongo State Institute For Islamic Studies, Semarang.

Fauzan, A. (2009). Using films to improve the ability of the eight graders of MTS N Planjan Kesugihan Cilacap in writing narrative paragraph (Unpublished master's thesis). Universitas Negeri Malang, Malang

Gusparia. 2014. Improving students' writing skill of narrative texts by using animation video at grade XI science 2 program of SMA N 1 Teluk Kuantan. Retrieved from http://ejournal.unp.ac.id/index.php lelt/article/download/4581/3623

Harmer, J. (2001). The practice of english language teaching 3rd Ed. Longman: Pearson Education. 
Huges, A. (2003). Testing for languange teachers. Cambridge: Cambridge University Press.

Ikhda, U.N. 2014. Improving students ' writing skill of descriptive text through guided questions (a classroom action research at the tenth grade students of SMAN 1 Karanganyar Demak in academic year 2013/2014). Retrieved from http://eprints.umk.ac. id/3213/1/hal_Judul.pdf.

Huy, N.T. (2015). Problems affecting learning writing skill of grade 11 at thong linh high school. Asian Journal of Educational Research, 3(2): 53-69.

Jayanti, A.D. (2015). Teaching narrative writing through guiding-questions technique at the second grade of SMA. Retrieved from http://jurnal.fkip.unila.ac.id/ index.php/123/article/view/9891.

Javed, M., Juan, W. X., \& Nazli, S. (2013). A study of students' assessment in writing skills of the english language. Online Submission, 6(2), 129-144.

Meliyanti, Sutapa, G., Husin, S. (2014). Improving students' recount text writing ability through guided questions technique. Jurnal Pendidikan dan Pembela- jaran, 3(7). Retrieved from http://jurnal.untan.ac.id/ index.php/jpdpb/article/view/6531.

Pertiwi, N. S., Purwati, O., \& Appl, M. (2013). The implementation of guiding question technique to teach writing recount text for the eighth graders of junior high school. RETAIN, 1(3). Retrieved from http:// ejournal.unesa.ac.id/index.php/retain/article/view/ 3784.

Raimes, A.(1983). Technique in teaching writing. New York: Oxford UniversityPress.

Rahman, U. (2012). Developing ability in writing recount text through guiding questions. Retrieved from http://www.lppm.stkippgri-sidoarjo.ac.id/files

Traver, R. (1998). What is a good guiding question?. Educational Leadership, 55(6), 70-73.

Zulfadlan, A., \& Arifin, T. M. (2013). Improving grade X students'achievement in writing narrative paragraph through animation movie. REGISTER Journal of English Language Teaching of FBS-Unimed, 2(1). Retrieved from http:// jurnal.unimed.ac.id/ 2012/index.php/eltu/article/.../615/429. 